\title{
Fenomén putování jako symbol duchovního rozměru osobnostního rozvoje v diskursu zážitkové pedagogiky
}

\author{
Ivo Jirásek \\ Univerzita Palackého v Olomouci, Fakulta tělesné kultury, Katedra rekreologie \\ Redakci zasláno 4. 9. 2013 / upravená verze obdržena 29.10. 2013 / k uveřejnění \\ přijato 4.11.2013
}

\begin{abstract}
Abstrakt: Text v diskursu filosofie výchovy hledá možná propojení informálního vzdělávání v rámci putovního kurzu Prázdninové školy Lipnice Život je gotickej pes a potenciálního rozvoje spirituálního rozměru lidského způsobu bytí. První část výkladu pojednává o oboru zážitková pedagogika a expedičním kurzu jako příkladu zvoleného diskursu. Druhá část se zaměřuje na spirituální rozměr lidského prožívání a jeho odlišení od témat náboženských. Třetí část konkretizuje spirituální prožitky v rámci popisovaného kurzu a předkládá nový model spirituálního (nenáboženského) putování. Struktura projektů realizovaných metodami zážitkové pedagogiky nabízí potenciál pro uchopení možností, jež s sebou nese nenábožensky pojatá spiritualita. Mezi fenomény strukturující tento rozměr prožívání patří duch, cesta, transcendence, transformace a smysl. Příspěvek tak upozorňuje, že zážitková pedagogika má ve své hloubce velmi blízko ke spiritualitě v její nenáboženské dimenzi a tím i k akcentaci autentického modu existence.
\end{abstract}

Klíčová slova: spiritualita, zážitková pedagogika, putování, smysl, filosofie výchovy, autenticita

Předložený příspěvek usiluje o filosofické uchopení spirituálního aspektu edukativního kurzu v rámci informálního vzdělávání a výchovy (ve smyslu odlišení formálního institucionálního vzdělávání, neformálního rozvoje na základě dobrovolnosti a edukace informální, spontánní, zájmové; blíže viz Houfbauer, 2004). Rádi bychom poukázali na implicitní duchovní rozměr a jeho předpoklady v informálním výchovném působení kurzů využívajících zejména pěšího putování jako svého programového prostředku. Tím míríme k intencím filosofie výchovy (Palouš, 1991; Michálek, 1996), jež je rozvíjena i na stránkách českých pedagogických časopisů (Palouš \& Prázný, 2007; Palouš, 2009; Pelcová, 2010). Naším záměrem však není péče o duši, jak v návaznosti na Patočkovu interpretaci Platóna rozvíjejí zmiňovaní autoři, ale

DOI: $10.5817 /$ PedOr2014-1-5 
poukaz na filosofický rozměr informální edukace, jak se vyjevuje v prostředí neformálního vzdělávání, konkrétně na zimním putovním kurzu Život je gotickej pes, pořádaném Prázdninovou školou Lipnice. Namísto péče o duši stojív centru naší výpovědi prožitek holisticky pojímané osobnosti (v rozměru nejenom tělesném a duševním, ale také sociálním a spirituálním).

\section{Kurz Život je gotickej pes jako projekt vedený metodami zážitkové pedagogiky}

Zastánci konceptu zážitkové pedagogiky tvoří prozatím spíše uzavřené společenství, jež promlouvá k odborné pedagogické veřejnosti zejména prostřednictvím kontaktů s př́buznými edukativními disciplínami (andragogika, dramatická výchova, artefiletika, sociální pedagogika, pedagogika volného času aj.), nikoliv však cílenou odbornou komunikací prostřednictvím pedagogických časopisů (ponecháme-li stranou specializovaný časopis Gymnasion, který však nebývá často reflektován jinými pedagogickými periodiky). Náš př́spěvek se tak ocitá na hraně jak z hlediska oborového vymezení (pedagogické deskripce edukativních procesů nesených reflexí záměrně vyvolané zkušenosti), tak tematického ohraničení (téma spirituality se sice v pedagogickém diskursu objevuje: Říčan, 2006; Misauerová, 2011, avšak prozatím je nelze označit za běžně analyzovaný fenomén v rámci české pedagogiky; v zahraničí je pozornost věnovaná tomuto tématu podstatně koncentrovanější: Zinn, 1997; Fenwick, 2001; Schmidt \& Little, 2007; Joldersma, 2009; Mayrl \& Oeur, 2009; Hogan, 2009).

V předloženém příspěvku považujeme zážitkovou pedagogiku (k širšímu kontextu viz např. Vážanský, 1992; Vážanský \& Smékal, 1995; Neuman, 1998; Jirásek, 2004) za teoretickou reflexi toho výseku reality, který je patrný na tzv. autorských kurzech Prázdninové školy Lipnice (PŠL). Zásadní důvody jsou zejména dva:

(a) Přestože se $\mathrm{v}$ dnešní době $\mathrm{k}$ fenoménu zážitkové pedagogiky hlásí velké množství organizací a uskupení (Instruktoři Brno, Hnutí Go!, Gymnasion, o.p.s., Velký vůz, Užitečný život, Educatio aj.), právě PŠL stála na počátku tohoto proudu (založena 1977), mnohé z organizací se k PŠL hlásí jako ke své inspiraci a tato pravděpodobně i nejzřetelněji usiluje o rozvoj metodiky formou programových inovací, pořádáním odborných konferencí a publikační aktivitou. 
(b) Ačkoliv se sousloví zážitková pedagogika používá nejenom pro teoretické analýzy, ale také pro označení realizace aktivit vedených touto metodikou (zážitková pedagogika jako praktický obor), domníváme se, že je potřeba takové nerozlišování razantně odmítnout. Stejně jako není možné ztotožňovat výchovu (předmět zkoumání) a pedagogiku (vědu) např. ve školním prostředí, nemůžeme ani samotné hry či programy na kurzu, byt' sjednocené dramaturgickou ideou, označovat za (zážitkovou) pedagogiku. Žel, dokud nebude využíván jiný vhodnější termín pro označení praktické činnosti (napřr. zkušenostní učení), bude se tato terminologická nepřesnost v praxi objevovat i nadále.

Projekty PŠL uváděné jako autorské kurzy (vedle kurzů metodických, na objednávku a dalších, často razantně odlišných) trvají nejméně sedm, avšak často více dní (např. kurzy Outward Bound, jehož je PŠL členem, v zahraničí mohou být i více než třítýdenní). Skupina, která se na nich setkává, má okolo 30 členů (např. 24 účastníků a 6 instruktorů). Jejich program je cíleně sestavený dle pravidel dramaturgie (termín je převzat z věd o umění, avšak obsahově se jedná o zcela specifický význam práce s místem, časem, cíli, tématy, programovými prostředky, lidmi aj.; v daném pedagogickém kontextu začal být využíván od přelomu 70. a 80. let 20. století: Gintel, 1982; Hora et al., 1984; Holec et al., 1994; Paulusová, 2004; Franc, Zounková, \& Martin, 2007; Drahanská, 2009; v zahraničí se hovoří o tzv. designu programu či kurzu: Martin, 2001; Martin, Franc \& Zounková, 2004; Leberman \& Martin, 2005; Martin \& Leberman, 2005). Takto připravené a realizované projekty zpravidla sledují cíle osobnostního rozvoje účastníkủ. Za tímto účelem používají jako prostředku především prožitek, který by měl být silný a osobní, aby mohl v člověku probouzet jeho autentické reakce. Skrze jeho reflexi v zážitkovém modu člověk přichází $\mathrm{k}$ hlubšímu vědomí sebe sama a svých možností, k získávání zkušeností přenositelných i do budoucího žití. Situace, které jsou na kurzu navozeny, navíc často směřují k tomu, aby účastník překročil svou osobní bezpečnou zónu a vykročil do nového nebo neznámého (Brown, 2008). Zážitkovou pedagogiku bychom tak mohli vymezit jako teoretickou deskripci výchovných procesů cíleného vystavení člověka situaci, která po něm žádá nasazení všech jeho sil, autentickou reakci a překročení horizontu známého nebo ozkoušeného. Právě v oblasti nového, při pohybu neznámým terénem pak může docházet $\mathrm{k}$ intenzivnímu učení a sebepoznávání. Jak se pokusíme ukázat později, je to právě tento moment vaktivitách reflektovaných zážitkovou pedagogikou, který umožňuje a podporuje zkušenost, kterou bychom mohli kvalifikovat jako spirituální. 
Pro následující úvahy vyjděme ze zkušenosti zimního expedičního kurzu Život je gotickej pes, který po dobu své osminásobné realizace procházel výraznými dramaturgickými proměnami. Začínal v roce 2000 jako pobytový kurz, aby se postupně rozšiřováním možností přímého kontaktu s realitou zimní přírody proměnil v kurzy kombinované a vyústil (alespoň prozatímně) v kurzy putovní. Na posledně jmenované, konkrétně na realizace v letech 2011 a 2012, se nyní zaměříme. Kurz byl rozčleněn na tři části: př́pravnou (víkendové setkání na podzim, které sloužilo ke zjištění fyzické připravenosti účastníků, pro předání informací a navození motivace k samostatné př́ípravě v následujících měsících), hlavní (lednové dvanáctidenní putování na sněžnicích na hranicích Slovenska a Polska v Bukovských vrších) a závěrečnou (trrídenní část v únoru, obsahující mj. celodenní výpomoc služby starým a nemocným v diakonii v Sobotíně a noční bdění na Rabštejně). Přestože pro fenomén spirituality nemůžeme opomíjet ani zkušenost závěrečné části kurzu, koncentrovat se chceme zejména na samotné putování. Aby však nezůstal opomenut podstatný význam, který může obohatit následující pasáže týkající se porozumění spiritualitě, doplňme ještě stručný komentář $\mathrm{k}$ faktu, že víkendové únorové setkání se seniory mělo nejenom poukázat na rozměr sociální solidarity, ale napomoci důrazu na interpersonální vztahy v životě účastníků obecně. Že došlo i k nečekanému edukativnímu transferu do pokurzovního života, dokládá příklad jednoho z účastníků, pro nějž byl právě tento prožitek prímého kontaktu se seniory potřebujícími pomoc impulsem k návštěvě a prohloubení vztahu s vlastní babičkou (Svoboda, 2013). Můžeme důvodně předpokládat, že se nejednalo o výchovný podnět ojedinělý a že bychom mohli téma rozvíjet s ohledem na rozměr mezilidských vztahů v dimenzi lásky křestanského pojetí agapé, tedy v onom modu hlubokého respektu k druhé lidské bytosti, nicméně tím by se rozsah textu neúměrně rozšířil.

Hlavní a časově nejrozsáhlejší část kurzu byla programově poměrně jednoduchá: při $113 \mathrm{~km}$ dlouhém přechodu si účastníci nesli veškeré potřeby jako stany, spací pytle, oblečení, vařiče, jídlo, nářadí atd. v batozích na zádech, po ukončení zhruba 10-12 km dlouhé denní etapy si postavili tábor, připravili večeři, nanosili dřevo na oheň, u něhož trávili večery s doprovodným programem, mj. recitací básní, zpěvem s kytarou, diskusemi nad přednáškami s filosofujícími tématy (např. turisté a poutníci, horizonty cest, živly, láska, smrt aj.). 
Domníváme se, že určité charakteristiky takových prožitků můžeme označit jako spirituální a že tyto vedou k holistickému rozvoji účastníků neformálního vzdělávání vedeného metodami zážitkové pedagogiky.

\section{Spirituální rozměr lidského způsobu bytí}

Pojem spirituality bývá často ztotožňován s religiozitou, zbožností či náboženstvím, je mu tedy vtiskován význam překročení běžného prožívání do ontologicky zcela odlišné reality. Je chápán jako vyjádření prožitků stojících mimo lidskou přirozenost, mimo možnosti obvyklého zakoušení a sdílení prostřednictvím slov, zcela mimo vědecké (či jiné racionální) uchopení. Přestože dané porozumění může být platné, pokusíme se pro naše potřeby odlišit od náboženské spirituality spiritualitu nenáboženskou. Důvodem je evidentní fakt, že zimní př́roda není primárně prostředím religiózním (jako např. chrám, poutní místo či další posvátné fenomény v podobě kultovních předmětů, osob aj.). Předpoklad, že popisovaný kurz může vzbuzovat i ryze náboženské prožitky (zejména u k tomu disponovaných jedinců), nemůžeme a nechceme odmítat, tento úhel pohledu však není prizmatem našeho sdělení.

Obvykle dochází ke směšování, resp. nedostatečnému odlišování obou fenoménů a odborníci zabývající se hlouběji výzkumem spirituality chápou její vazbu na religiozitu různě: pro jednoho je odlišující charakteristikou koncept boha (Emmons \& Crumpler, 1999), pro dalšího je spiritualita jakýmsi centrem („heart and soul“) náboženství a hledání sakrálního je hlavní náboženskou funkcí (Pargament, 1999), jiný naopak vnímá spiritualitu jako širší koncept, než je náboženství (Stifoss-Hanssen, 1999). Spiritualita může být nahlížena jako „hledání posvátného“ (Pargament, 1999, s. 12), ale také jako „lidské hledání smyslu, v relaci k velkým existenciálním otázkám“ (Stifoss-Hanssen, 1999, s. 28). Kromě posvátna či existenciality může být za centrum spirituality vydáván také vztah, hluboká vazba k ostatním, k př́rodě a k „vyššímu bytí“ (Reich, 2000).

Přitom k odlišení religiózního (náboženského) a spirituálního rozměru opravňují i výsledky empirických šetření, které deklarují odlišné vnímání religiozity a spirituality. $\mathrm{V}$ jednom z nich se $93 \%$ respondentů identifikovalo s pozicí „spirituální", ale pouze 78 \% s postojem „religiózní a různí respondenti odlišně vnímají překrývání i odlišení těchto pojmů (Zinnbauer et al., 1997). Jiný výzkum poukazuje na fakt, že spiritualita je osobně významná 
pro $71 \%$ respondentů, ale pouze $9 \%$ ji vykazovalo v propojení s tradičním náboženstvím a $74 \%$ indikovalo, že náboženství není primárním zdrojem jejich spirituality (Elkins et al., 1988).

V tomto textu vycházíme $\mathrm{z}$ jasného odlišení náboženského a spirituálního rozměrulidských prožitků. A přestoženenímožnétyto pojmysvázatdefiničním výměrem sensu stricto, pokusíme se o hlubší porozumění odlišnostem na základě rozdílu, jenž akcentoval již v 50. letech Mircea Eliade (2006), když rozlišil dvě zcela odlišné roviny či dva rozměry lidského způsobu bytí, totiž rovinu sakrální (religiózní, posvátnou) a profánní (sekulární, světskou). Zároveň upozornil na fakt, že posvátné se ukazuje v procesu hierofanie jako něco odlišného od profánního. Hledání sakrálního je náboženskou funkcí, bez níž by náboženství nebylo náboženstvím. A sacrum je sféra ontologicky odlišná od běžného lidského prožívání, je to oblast „absolutně jiného“. Relevantní literatura autorit oboru naznačuje, že náboženství je zkušeností člověka ve vztahu k božstvu, at' už se za ně považuje cokoliv (James, 1930), základní složkou náboženství je posvátno a pocit mysteria tremenda (Otto, 1998), náboženství je vztahem člověka $\mathrm{k}$ tomu, co má vůči němu roli boha, tedy $\mathrm{k}$ něčemu, co jej přesahuje a na čem je závislý (Heller \& Mrázek, 1988 ) atd. Náboženská zkušenost zkrátka předpokládá sféru ontologické transcendence, sféru odlišnou od profánní každodennosti, sféru sakrální jinakosti. Pokud bychom vnímali prožitky v rámci popisovaného kurzu jako náboženské, museli bychom nutně označit takové putování za religiózní poutt.

Naproti tomu spiritualita je rozměrem povýtce lidského způsobu bytí. Jestliže sakrální (religiózní) je nemyslitelné bez božství, tedy bez významu posvátného, za oblast spirituality můžeme považovat lidskou transcendenci, ovšem nikoliv k „absolutně jinému“, ale k hlubšímu uvědomování si bytí sebe samého (autenticita) v lidské komunitě (společenství). Je-li pro náboženství podstatná sféra posvátného (sacrum), pro spiritualitu je to zejména oblast smyslu života (již Frankl, 1994, 1997 přesvědčivě zdůvodnil, že smysl života se nenachází v oblasti duše, ale ducha). Základní kategorií spirituálního rozměru lidského prožívání v procesu seberealizace je smysluplnost, jejímiž indikátory mohou být vysoké ideály a hluboké ideje, vize a poslání, víra ve smysl. Výměrem spirituality může být existencialita, nikoliv posvátno, jež je základní charakteristikou náboženství. Duch (spiritus) je „dech života“, jeho projevem je proměna a vanutí, projevy vzdušného živlu. To však neznamená, že je něčím „nadpřirozeným“, ale spíše přesahem danosti, svobodou a vertikálním směřováním. Potenciálně nenáboženských vymezení 
spirituality existuje celá řada, pro naše potřeby by plně vyhovovalo např. pojetí I. O. Štampacha, pro něhož je spiritualita „péče člověka o sebe a jiné lidi mající za cíl, aby se člověk vracel z odcizení $\mathrm{k}$ sobě a v této autenticitě ze sebe vystupoval. Je to péče o to, abychom byli více sebou a více lidmi“ (Štampach, 2006, cit. podle Babyrádová \& Havlíček, 2006, s. 104). Rovněž v návaznosti na Maxe Schelera (1968) se můžeme pokusit revitalizovat jeho pojetí ducha jako bytostně personálního principu, který specificky charakterizuje způsob bytí člověka. Toto téma však bude koncentrovaněji pojednáno později.

Z toho vyplývá, že spiritualita, která může být i součástí vstupu do oblastí posvátných a nabývat tak religiózních konotací, může být v jiném významovém rámci čistě nenáboženská, nevázaná na jinou realitu božství (posvátnosti), ale spíše na symbol hledání smyslu, na vertikální rozměr lidského života (Jirásek, 2013). Domníváme se, že právě takový rozměr prožitků můžeme detekovat při putování v kontextu zážitkového kurzu PŠL Život je gotickej pes.

\section{Spirituální prožitky při zimním putování na sněžnicích}

Fenomény, které podle našeho názoru výrazněji vystupují jako složka prožívání při reflexi putování na sněžnicích zimní krajinou v kontextu kurzu PŠL Život je gotickej pes, lze strukturovat do pěti základních momentů: duch, cesta, transcendence, transformace, smysl. Tato distinkce není dána empirickým šetřením (při analýze rozhovorů s účastníky se ukazují jako významuplné zejména kategorie př́rody a živlů, komunity, specifické časovosti s koncentrací na přítomnost a prvek překonávání, tedy jistého modu transcendence), ale filosofickou analýzou podnícenou účastnickou a instruktorskou introspekcí komparovanou se studiem relevantní literatury.

Metodologicky tak můžeme nahlížet na vybrané fenomény jako na významové momenty při hermeneutickém rozkrývání smyslu (rezignujeme tedy na vědecký ideál vysvětlení a kloníme se $\mathrm{k}$ hermeneutickému důrazu na porozumění), k němuž napomohlo mj. porovnání s aspekty charakteristickými pro vytyčování spirituality jinými autory. Elkins se spolupracovníky (1988) vytváří katalog spirituální orientace a rozlišuje devět komponent: transcendentní dimenze, smysl a účel života, životní poslání, posvátnost života, materiální hodnoty, altruismus, idealismus, vědomí tragičnosti a plody spirituality. Nikoliv úplný výčet, ale spíše ukázku znaků, jimiž se spiritualita projevuje, podává Stifoss-Hanssen (1999): propojenost (souvislost - connectedness), autenticita, smysl života, holismus, já, komunita apod. Při pokusu odlišit spi- 
ritualitu od náboženství bývá uváděno její spojení s funkcionálním přístupem, s individualizací, personální transcendencí, mimovědomou sensitivitou a smysluplností, je asociována s mystickými zážitky, s New Age vírou a praktikami, s fundamentálními problémy existence jako je smysl, smrt, izolace, utrpení a nespravedlnost, hodnotově je vnímána spíše pozitivně (Zinnbauer et al., 1997; Zinnbauer et al., 1999; Pargament, 1999). Jako poslední ukázku vzpomeňme 6 faktorů spirituality, které vytyčil Lapierre (1994): cesta (hledání smyslu), transcendence (úroveň reality překračující běžnou lidskou zkušenost), společenství, náboženství, „mysterium tvorby“ (vazba na přírodní prostředí) a transformace.

$\mathrm{Z}$ této stručné rekapitulace lze snadno vyvodit evidentní rozporuplnost v náhledech jednotlivých autorů. Ba dokonce nejsou bez problémů ani jednotlivé systémy bez komparace s ostatními (např. v poslední zmíněné ukázce je transformace popisována velmi obdobně jako cesta). Z toho pramení, že chceme-li využít myšlenkového experimentu, na němž je filosofie založena, musíme být schopni předložit takové deskripce, které nebudou v rozporu s celkovou konstrukcí textu a budou vnitřně bezrozporné. Náš poukaz na jeden z možných modelů uchopení spirituálního rozměru života $\mathrm{v}$ konkretizaci jednotlivých kategorií se navíc neomezuje výlučně na intelektuální rozměr diskuse, ale pokouší se ověřit nabízené fenomény rovněž konkretizací poukazů na prožívanou realitu a tím ještě více prohloubit hermeneutický důraz na porozumění.

\subsection{Duch}

Max Scheler ve své knize Die Stellung des Menschen im Kosmos $\left(1928^{1}\right)$ popisuje mj. odlišnost člověka od zvířat a tvrdí zde, že podstata člověka se nevyčerpává praktickou inteligencí jakožto vrcholem stupňovité antropologie (kvalitativně následující po návykovém chování, instinktech a pudech). Pro označení principu, který specificky charakterizuje způsob bytí člověka, volí slovo, jež zahrnuje nejenom rozum, ale také myšlení v idejích, určitý druh nazírání podstatných obsahů, stejně jako skupinu volních a emotivních aktů, jako je láska, úcta, blaženství, svoboda apod., totiž slovo duch (der Geist). Centrem projevů ducha je osoba a jeho základním určením pak existenciální odpoutanost od organického, totiž svoboda, „otevřenost vůči světu“. Duch je bytím nepředmětným, je ryzí aktuálností, způsob jeho bytí je ve výkonu svých aktů:

1 Pro přesnější porozumění byl používán rovněž český překlad (Scheler, 1968). 
Duch je jediné bytí, jež samo je neschopné zpředmětnění, - je čistou, ryzí aktuálností, má své bytí jen ve svobodném výkonu svých aktů. Centrum ducha, „osoba“, není ani předmětné, ani věcné bytí, nýbrž ustavičně sama sebe uskutečňující (podstatnou zákonitostí určená) řádoslovná skladba aktů. Osoba je pouze ve svých aktech a skrze ně. ${ }^{2}$ (Scheler, 1968, s. 74)

Vnímání ducha jako bytostně personálního jsoucna, jako projevu podstatně lidského způsobu bytí, se na popisovaném kurzu vyjevuje v modu individualizačního přístupu jedinců k druhým lidem, k prostředí, v němž kurz probíhá, k přírodním podmínkám a nutností přizpůsobit se. Zkrátka „otevřeností vưči světu“ jak ve významu adaptace se na prostředí a podmínky, tak v projevech svobody a zájmu o hlubší rozměry života. Situace, které překračují modus každodennosti, umožňují nahlédnout na způsob svého života z jiné perspektivy, reflektovat své jedinečné životní směřování.

\subsection{Cesta}

Symbol cesty je snad nejčastějším obrazem ze spirituálního okruhu idejí. Jako první spojitost zřejmě vytane každému na mysli „tao“ z čínského spirituálního okruhu (Lao-c', 2008). Útlá knížečka naznačuje svým podtitulem $O$ tajemství hlubším než hlubina sama, že se prostřednictvím slov dostáváme do sfér, které lze vyjádřit jen s největšími obtížemi. V souvislosti s popisovanými prožitky na kurzu Život je gotickej pes nás však nebude zajímat ani ontologický rozměr symboliky cesty, ani etické aspekty této mudroslovné literatury. Při pěším putování na sněžnicích zimní přírodou spíše v mysli rezonuje téma cíle a cesty (už jenom pro souvislost cesty jako způsobu dopravení se někam, tedy prostředku, jak se dostat k cíli, náznakem ještě zachované ve slovu metoda, ve starší pravopisné podobě methoda: hodos = cesta). Zpomalení chůze může podněcovat úvahy o cestě a cíli, o oblíbeném úsloví „i cesta může být cíl“, a to nejenom v konkrétní podobě denní etapy, ale i ve spirituální symbolice cesty životní. Dnešní společnost, preferující machiavelisticky dosažení cíle bez ohledu na použité prostředky, redukuje bohatost života. Dosažený cíl bez vynaložené námahy totiž nemůže mít plnou svoji hodnotu, přesto je např. soudobý sport v krizi právě proto, že se mnohem větší dưraz

2 „Der Geist ist das einzige Sein, das selbst gegenstandsunfähig ist - er ist reine und pure Aktualität, hat sein Sein nur im freien Vollzug dieser seiner Akte. Das Zentrum des Geistes, die Person, ist also weder gegenständliches noch dingliches Sein, sondern nur ein in sich selbst stetig selbst sich vollziehendes (wesenhaft bestimmtes) Ordnungsgefüge von Akten." (Scheler, 1928, s. 58) 
klade na výsledky, nikoliv důsledky (Oborný, 2001). Úspěch by neměl být roven pouze výslednému stavu, ale rovněž investované námaze potřebné k jeho dosažení.

\subsection{Transcendence}

Transcendencí nerozumíme v daném kontextu překročení „lidskosti“ do posvátných sfér náboženství, ale přirozenou součást lidského způsobu bytí: spirituální transcendence totiž byla identifikována jako samostatný faktor či dimenze v psychologickém modelu osobnosti (Piedmont, 1999). Překročení modu každodennosti a běžného obstarávání tak můžeme vnímat v neobvyklosti prostředí i pohybové aktivity samotné, ale zejména $\mathrm{v}$ hlubších dimenzích jako ochotu vykročit stranou z obvykle vnímaného času a prostoru vlastního života. Tento odstup pak může být zesílen dramaturgickým záměrem instruktorského týmu, vyjevujícím se např v programu navštívením obce Osadné, diskusí s pravoslavným popem a návštěvou krypty s pozůstatky vojáků z první světové války (na zdejších kopcích vedla válečná fronta, s pozůstatky patrnými do dnešních dnů). Smrt je sice rysem veškerého př́irodního dění (k modu přirozenosti patří vznik, tedy zrození, růst, ale také stárnutí a zánik - moment, který soudobá kultura vytlačuje spíše do nevědomí postmoderní estetizací důrazem na kult výkonnosti a mládí), ale vědomí smrti je konstitutivním prvkem lidství: zviŕre hyne, pouze člověk umírá. Na Freudovo (1991) rozlišení pudu života (bios) a pudu smrti (thanatos) navazuje Fromm (1969) rozlišením lidí na ty, kteří milují život (biofilové), a na ty, kteří milují smrt (nekrofilové). Na rozdíl od projevů života (vznik nového, růst) miluje nekrofilní osoba anorganické uspořádání, tj. vše mechanické, zvěcnělé, kontrolovatelné, jisté. Vše bující proměňuje v řád, vše živé ve věci, na rozdíl od modu být preferuje statut mít. Žretelným opakem je pak tvořivá orientace biofilie: proces a růst, změna oproti zachování starého stavu, kreativní konstruování nově přicházejících možností, obdiv k novému před jistotou již ověřeného minulého. „Spíše než bezpečí miluje dobrodružnost života“ (Fromm, 1969, s. 36).

Volbou nepohodlí, jisté míry dobrodružství a nezbytností přizpůsobovat se prŕírodním podmínkám se účastníci kurzu Život je gotickej pes řadí spíše k biofilně orientovaným jedincům. Zima se svojí sněhovou pokrývkou a chladem, netečným okolím, $v$ jehož centru hoří oheň jako základní strukturotvorný prvek řádu a života, však může akcentovat úvahy o smrti s ohledem nikoliv na nějaké racionální argumenty, ale s možností vztaženosti k sobě 
samému, k onomu Heideggerovu vyklonění se do nicoty: „Tím, že se pobyt drží vykloněn do Ničeho, vykročil již vždy za jsoucno v celku. Toto vykročení za rámec jsoucna nazýváme transcendence" (Heidegger, 1993, s. 55). Existenciální prožitek „bytí-ke-smrti“ teprve umožňuje autentickou existenci, jíž se budeme blíže věnovat v posledním rysu vymezujícím spiritualitu pohybu na sněžnicích.

\subsection{Transformace}

Proměna vlastního způsobu žití, odvaha ke změně a síla změnit návyky vlastního stereotypního uvažování i jednání patří k rysům, jež pedagogické působení a spirituální rozvrh lidského způsobu bytí propojuje nejzřetelněji. Možnost proměny předpokládá především ochotu opustit jistoty a bezpečí, vydat se do nezajištěné budoucnosti, směrem k proměně. To je de facto rys všech cest, zejména poutnických. Akceptovat nový úhel pohledu, přijmout změnu jako bytostnou součást svého života.

Proměna a adaptace je nezpochybnitelná již na fyzické úrovni existence, kdy obtíže putování, bolest a vynaložené množství energie na pouhé udržení základních potřeb poukazují na nezbytnost překonat sám sebe. Sebepřesah a mobilizace sil jsou patrné např. u snížení potřeb na ty nejzákladnější, současně však otevírající obrovský prostor pro sebereflexi, přehodnocování vlastního způsobu bytí a plánování případných změn budoucího života. Mnohem zřetelněji se vyjevuje bytí v celku, bez disipace na jednotlivé dílčí elementy (sociální role, konkrétní úkoly, povinnosti a vyplňování času), jimiž se obvykle zabýváme.

\subsection{Smysl}

Horizont smyslu života a jeho hledání je rozeznatelný pouze hermeneutickým ohledáváním celkového životního naplnění prostřednictvím smysluplných jednotlivých aktivit, činností. Možné cesty, v nichž lidé spatřovali a spatřují smysl svého života, rekapituluje Machovec (2004):

- náboženská odpověd’ (i v naší „nejateističtější“ zemi je patrný příklon k různým religiózním a spirituálním proudům, což značí hledání určité paralely ke zvěcnění člověka);

- hédonismus (radost a poživačnost z živočišné stránky života, ale také pouhý konzum hodnot kulturních); 
- činnost (práce, seberealizace ve společenském uplatnění, jehož kulturním symbolem se stává Faust);

- rezignace (odmítnutí nejenom jednotlivých koncepcí smyslu života, ale skepse vưči otázce samé, často propojené s vnímáním života jako absurdity).

Zdá se, že smysl života můžeme v obecné rovině směle ztotožnit s tím, co Heidegger (1996) nazývá autentickým modem existence. Jeho opak, neautentické bytí, znamená, že s možnostmi našeho života nakládají druzí, kteří však nejsou konkrétními jednotlivci, ale neosobním „ono se“. Existenciálním rysem tohoto „ono se“ je průměrnost. Průměr toho, co se sluší, co se dělá, co se nosí, co platí a co neplatí, co je úspěšné a co nikoliv. Průměrnost jako omezení osobní individuality, svébytnosti a výjimečnosti je příznakem moci neosobního „ono se“. Diktát módy, reklamy, trhu či byrokratické moci, kterému podléháme, je svědectvím ztráty naší autenticity, nebot' se nejedná o př́ikaz konkrétního jedince, nýbrž o naše podřízení se něčemu neosobnímu, neurčitému. Přejít z této rozptýlenosti, nesoustředěnosti a nekoncentrovanosti k sobě samému, k výslovně uchopenému „bytí sebou“ je znakem autenticity. Účastníky dosvědčené hlubší přemítání o vlastním životě, o hodnotách, o smyslu, pak naznačuje, že chůze na sněžnicích zimní přírodou, v kontextu vhodně dramaturgicky promyšleného doprovodného programu, může být jedním z impulsů, jak reflektovat způsoby svého žití a usilovat o autentickou existenci jakožto naplnění smyslu svého života.

\section{Putování jako spirituální podoba nenáboženské pouti}

Při pokusu o jistou míru zobecnění, co může být podstatou cesty v diskursu projektu vedeného prostředky zážitkové pedagogiky, si můžeme pomoci obrázkem (obr. 1).

V části tohoto př́spěvku věnující se spiritualitě jsme upozornili na odlišení náboženské oblasti (sakrální) a sféry sekulární (profánní). Druhou osou, která nás u reflexe cest musí zajímat, je rozdíl mezi turistickou cestou a poutnickým modem cestování (Jirásek, 2011). Zatímco většinově je za poutnictví považována návštěva sakrálních památek, míst spojených s náboženským kultem, domníváme se, že na základě výše podané rekapitulace můžeme model obohatit o fenomén spirituality, který lze vnímat rovněž v modu autentické existence. 


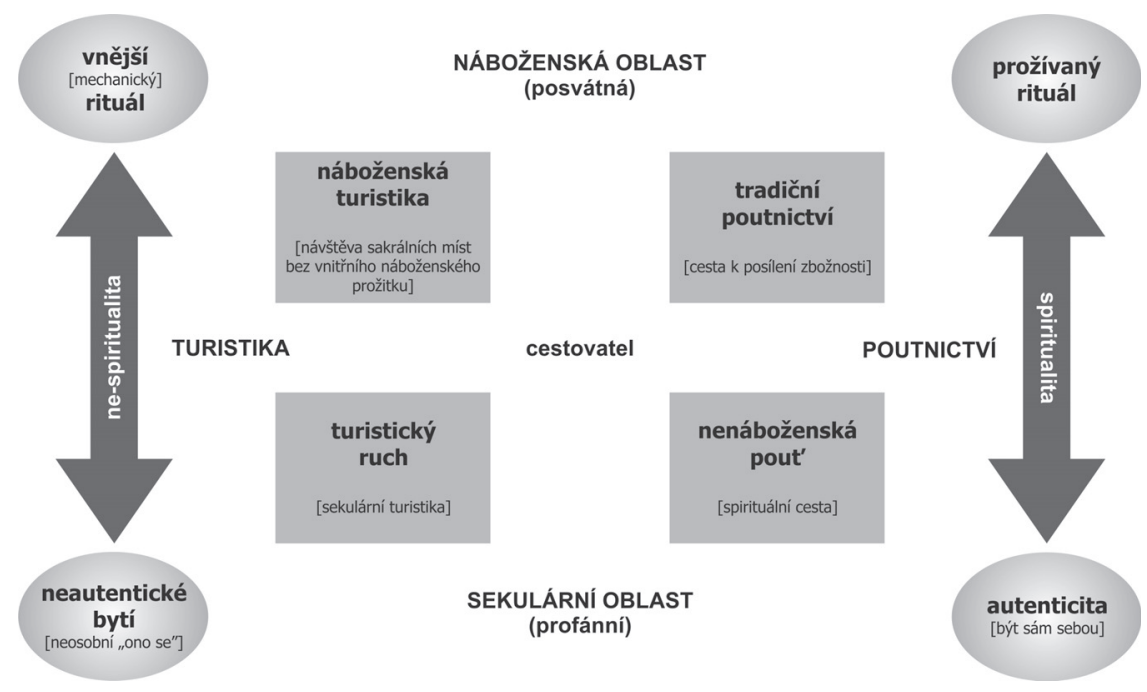

Obrázek 1. Model spirituálního (nenáboženského) putování.

V takovém př́ípadě pak můžeme cestovatelské prožitky vnímat jak v oblasti náboženské (přičemž můžeme rozlišit mezi turistickou návštěvou místa bez vnitřního prožitku, a naopak tradiční poutnictví jako cestu ke zvýšení zbožnosti), tak v oblasti profánní, (kam patři obvyklé turistické návštěvy, ale také spirituální cesty, jež můžeme označit jako nenáboženské pouti - právě k nim se řadí prožitky účastníků analyzovaného projektu).

Kurz Život je gotickej pes, jemuž jsme se v př́spěvku podrobně věnovali, můžeme zařadit do pravého dolního kvadrantu, a označit jej tedy za spirituální (nenáboženské) putování.

\section{Závěrem}

Jednotlivé fenomény informálního vzdělávání v projektu Prázdninové školy Lipnice, jak se vyjevují při chůzi na sněžnicích zimní přírodou na kurzu Život je gotickej pes, lze jistě detekovat a tematizovat i prostředky vzdělávání formálního. Přesto bychom rádi zdůraznili, že možnost transferu založená na osobním, existenciálním prožitku a nikoliv pouze na racionální reflexi diskursivní vykazatelnosti (s možnou redukcí prožitkové situace), 
často bez verbalizace a nadměrné racionalizace, může být svým způsobem radikálnější, hlubší a $\mathrm{k}$ podstatě autentického způsobu bytí zřetelněji směřující. Neformální a informální vzdělávání prostřednictvím přímých interpersonálních kontaktů tak obohacují edukativní rozměr naší společnosti o dimenze, které byly v tradičních společenstvích pojímány jako klíčové, ale které se v současnosti vytrácejí pod tlakem pragmatického přizpůsobování se výkonovým parametrům. Právě v tom může spočívat hodnota a smysl takto vedených aktivit. Projekty vedené metodami zážitkové pedagogiky se zdají otevírat možnosti zjevování spirituálního rozměru života, díky čemuž je rovněž možné nahlížet zážitkovou pedagogiku perspektivou spirituality.

\section{Literatura}

Babyrádová, H., \& Havlíček, J. (Eds.). (2006). Spiritualita: fenomén spirituality z pohledu filosofie, religionistiky, teologie, literatury, teologie a dějin umění, pedagogiky, sociologie, antropologie, psychologie a výtvarných umělců. Brno: Masarykova univerzita.

Brown, M. (2008). Comfort zone: Model or metaphor? Australian Journal of Outdoor Education, 12(1), 3-12.

Drahanská, P. (2009). Puzzle a bábovky. Gymnasion, 6(11), 47-54.

Eliade, M. (2006). Posvátné a profánní. Praha: Oikoymenh.

Elkins, D. N., Hedstrom, L. J., Hughes, L. L., Leaf, J. A., \& Saunders, C. (1988). Toward a humanisticphenomenological spirituality: Definition, desription, and measurement. Journal of Humanistic Psychology, 28(4), 5-18.

Emmons, R. A., \& Crumpler, C. A. (1999). Religion and spirituality? The roles of sanctification and the concept of God. The International Journal for the Psychology of Religion, 9(1), 17-24.

Fenwick, T. J. (2001). Critical questions for pedagogical engagement of spirituality. Adult Learning, 12(3), 10-12.

Franc, D., Zounková, D., \& Martin, A. (2007). Učení zážitkem a hrou. Brno: Computer Press.

Frankl, V. (1994). Člověk hledá smysl: úvod do logoterapie. Praha: Psychoanalytické nakladatelství J. Kocourek.

Frankl, V. (1997). Vůle ke smyslu: vybrané přednášky. Brno: Cesta.

Freud, S. (1991). Vybrané spisy I. Praha: Avicenum.

Fromm, E. (1969). Lidské srdce. Praha: Mladá fronta.

Gintel, A. (1982). Obrana vůdčích myšlenek aneb dramaturgie. Metodické listy pro tělovýchovně brannou činnost, 10(2), 7-9.

Heidegger, M. (1993). Co je metafyzika? Praha: ISE.

Heidegger, M. (1996). Bytí a čas. Praha: Oikoymenh.

Heller, J., \& Mrázek, M. (1988). Nástin religionistiky: uvedení do vědy o náboženstvích. Praha: Kalich.

Hogan, M. J. (2009). On spirituality and education. Thinking Skills and Creativity, 4(2), 138-143.

Holec, O., et al. (1994). Instruktorský slabikář. Praha: Prázdninová škola Lipnice. 
Hora, P., et al. (1984). Prázdniny se šlehačkou. Praha: Mladá fronta. James, W. (1930). Druhy náboženské zkušenosti. Praha: Melantrich. Jirásek, I. (2004). Vymezení pojmu zážitková pedagogika. Gymnasion, 1(1), 6-16.

Jirásek, I. (2011). Pilgrimage as a form of physical and movement spirituality. In J. Parry, M. Nesti, \& N. Watson (Eds.), Theology, ethics and transcendence in sports (s. 223-232). New York: Routledge.

Jirásek, I. (2013). Verticality as non-religious spirituality. Implicit Religion, 16(2), 191-201.

Joldersma, C. W. (2009). A spirituality of the desert for education: The call of justice beyond the individual or community. Studies in Philosophy and Education, 28(3), 193-208.

Lao-c'(2008). Tao te tíng. Praha: Dokořán.

Lapierre, L. L. (1994). A model for describing spirituality. Journal of Religion and Health, 33(2), 153-161.

Leberman, S. I., \& Martin, A. J. (2005). Applying dramaturgy to management course design. Journal of Management Education, 29(2), 319-332.

Machovec, M. (2004). Smysl lidské existence. Praha: Akropolis.

Martin, A. J. (2001). Dramaturgy: A holistic approach to outdoor education. Australian Journal of Outdoor Education, 6(1), 34-41.

Martin, A., Franc, D., \& Zounková, D. (2004). Outdoor and experiential learning: A holistic and creative approach to programme design. Aldershot: Gower Publishing.

Martin, A. J., \& Leberman, S. I. (2005). Personal learning or prescribed educational outcomes: A case study of the Outward Bound experience. Journal of Experiential Education, 28(1), $44-59$.

Mayrl, D., \& Oeur, F. (2009). Religion and higher education: Current knowledge and directions for future research. Journal for the Scientific Study of Religion, 48(2), 260-275.

Michálek, J. (1996). Topologie výchovy: místo výchovy v životě. Praha: Oikoymenh.

Misauerová, A. (2011). Současné pojetí spirituality jako zdroj úvah o utváření prosociálních postojů. Pedagogika, 61(3), 248-256.

Neuman, J. (1998). Dobrodružné hry a cvičení v prŕrodě. Praha: Portál.

Oborný, J. (2001). Filozofické a etické pohlady do športovej humanistiky. Bratislava: Slovenská vedecká spoločnost' pre telesnú výchovu a šport.

Otto, R. (1998). Posvátno: iracionalita v ideji božství a její poměr k racionalitě. Praha: Vyšehrad.

Palouš, R. (1991). K filosofii výchovy: východiska fundamentálníagogiky. Praha: Státní pedagogické nakladatelství.

Palouš, R. (2009). Ontologický smysl výchovy. Pedagogika, 59(4), 341-349.

Palouš, R., \& Prázný, A. (2007). Pedagogické založení filosofie u Jana Patočky. Pedagogika, 57(2), 108-113.

Pargament, K. I. (1999). The psychology of religion and spirituality? Yes and no. The International Journal for the Psychology of Religion, 9(1), 3-16.

Paulusová, Z. (2004). Smysl a význam dramaturgie při přípravě akcí zážitkové pedagogiky. Gymnasion, 1(1), 85-89.

Pelcová, N. (2010). Jak si rozumíme? (Filosofická východiska pojetí výchovy u Janusze Korczaka). Pedagogika, 60(1), 4-11.

Piedmont, R. L. (1999). Does spirituality represent the sixth factor of personality? Spiritual transcendence and the Five-Factor Model. Journal of Personality, 67(6), 985-1013. 
Ivo Jirásek

Reich, K. H. (2000). What characterizes spirituality? A comment on Pargament, Emmons and Crumpler, and Stifoss-Hansen. The International Journal for the Psychology of Religion, $10(2), 125-128$.

Říčan, P. (2006). Spiritualita jako základ mravní výchovy. Pedagogika, 56(2), 119-131.

Scheler, M. (1928). Die Stellung des Menschen im Kosmos. Darmstadt: Otto Reichl Verlag.

Scheler, M. (1968). Místo člověka v kosmu. Praha: Academia.

Schmidt, C., \& Little, D. E. (2007). Qualitative insights into leisure as a spiritual experience. Journal of Leisure Research, 39(2), 222-247.

Stifoss-Hanssen, H. (1999). Religion and spirituality: What a European ear hears. The International Journal for the Psychology of Religion, 9(1), 25-33.

Svoboda, J. (2013). Interpretativní fenomenologická analýza zkušenosti účastníka kurzu PŠL Život je gotickej pes (Diplomová práce). Olomouc: Univerzita Palackého.

Vážanský, M. (1992). Volný čas a pedagogika zážitku. Brno: Nakladatelství Masarykovy univerzity.

Vážanský, M., \& Smékal, V. (1995). Základy pedagogiky volného času. Brno: Paido.

Zinn, L. M. (1997). Spirituality in adult education. Adult Learning, 8(5/6), 26-30.

Zinnbauer, B. J., Pargament, K. I., Cole, B., Rye, M. S., Butter, E. M., Belavich, T. G., Hipp, K. M., Scott, A. B., \& Kadar, J. L. (1997). Religion and spirituality: Unfuzzying the fuzzy. Journal for the Scientific Study of Religion, 36(4), 549-564.

Zinnbauer, B. J., Pargament, K., \& Scott, A. B. (1999). The emerging meanings of religiousness and spirituality: Problems and prospects. Journal of Personality, 67(6), 889-919.

\section{Autor}

Prof. PhDr. Ivo Jirásek, Ph.D., Univerzita Palackého v Olomouci, Fakulta tělesné kultury, Katedra rekreologie, Třr. Míru 115, Olomouc 771 11, e-mail: ivo.jirasek@upol.cz

\section{Wandering phenomenon as a symbol of spiritual dimension in personal development in experiential education discourse}

Abstract: Text, written in philosophy of education discourse, looks for a possible interconnection between informal education within the wandering course of Lipnice Vacation school "Life is a gothic dog", and the potential development of human being's in its spiritual dimension. The first part deals with experiential education and expedition courses as an example of the selected discourse. The second part concentrates on spiritual dimension of human experiencing and its differentiation from religious topics. Third part concretizes spiritual experiences in framework of described course and offers a new model of spiritual (non-religious) wandering. The structure of experiential education projects offers a potential of non-religious 
spirituality. We put spirit, journey, transcendence, transformation and meaning among phenomena which open such dimension of experiencing. The paper confirms that experiential education is in its depth near to non-religious spirituality and then to accentuation of authentic modus of existence.

Keywords: spirituality, experiential education, wandering, meaning, philosophy of education, authenticity

Píšová, M., et al. (2011). Teorie a výzkum expertnosti v učitelské profesi. Brno: Masarykova univerzita.

Publikace představuje přehledovou studii věnovanou tématu expertnosti v učitelství a procesu jejího utváření. $V$ úvodu knihy jsou prezentovány obecné teorie expertnosti a různá pojetí uplatňovaná v různých oborech lidské činnosti. Dále jsou představeny modely učitele a jeho profesního učení a pojetí expertnosti a expertního výkonu v učitelství, která na těchto modelech staví, a to s akcentem na učitelství cizích jazyků. Závěr knihy je věnován determinantám rozvoje expertnosti u učitelů cizích jazyků.

Gulová, L., \& Šíp, R. (Eds.). (2013). Výzkumné metody v pedagogické praxi. Praha: Grada.

Publikace nabízí výběr z tradičních i méně tradičních analytických metod, jež lze využít $\mathrm{k}$ výzkumu pedagogické reality (zakotvená teorie, analýza konstituce významů, diskursivní analýza a další). Nabízí všem, kdo se zajímají o pedagogiku nebo výchovu, a zejména těm, kdo se těmto oborům věnují profesně, úvod do práce s jednotlivými metodami. Každá kapitola se věnuje jinému způsobu analýzy a poskytuje popis jeho teoretických východisek a postupů. Vše je dokumentováno na konkrétních výzkumech, které již byly pomocí zmíněných metod realizovány. Čtenáři se tak seznámí s výzkumy prováděnými např́klad v oblasti multikulturní výchovy, zacílenými především na situaci sociálně znevýhodněných skupin, přičemž nahlédnou do aplikačních mechanismů jednotlivých metod a do výsledků výzkumných šetření. Zmíněné přístupy lze využít ve výzkumech dalších sociálních a humanitních věd. 